\title{
THE IMPLEMENTATION OF DRILL EXERCISE VARIATIONS IN BASKETBALL LECTURING (CHEST PASS TECHNIQUE) AT THE STUDENTS OF PHYSICAL EDUCATION IN UNIVERSITY OF DEHASEN BENGKULU
}

\author{
${ }^{1}$ Arifto Juniardi, ${ }^{2}$ Tito Parta Wibowo \\ Correspondence: University of Dehasen Bengkulu, Bengkulu, Indonesia \\ E-mail: ariftojuniardi@unived.ac.id
}

\begin{abstract}
Abstrak
Penelitian ini bertujuan untuk meningkatkan hasil belajar chest pass bola basket yang memiliki tingkat keberhasilan rendah. Berdasarkan masalah di atas maka perlu dilakukan perbaikan dalam proses perkuliahan, sehingga target hasil belajarr mencapai nilai KKM. Keberhasilan dalam perkuliahan adalah saat nilai KKM yang telah ditetapkan oleh program studi tercapai. Jenis penelitian yang digunakan adalah penelitian tindakan kelas dengan subyek penelitian mahasiswa yang mengikuti perkuliahan bola basket dan dosen pengampu mata kuliah bola basket. Populasi dalam penelitian ini adalah Mahasiswa Prodi Penjas Universitas FKIP Dehasen Bengkulu, sampelnya adalah mahasiswa Prodi Penjas Semester V Kelas A1. Pada awal perkuliahan telah diberikan materi chest pass, akan tetapi mahasiswa masih terdapat kesulitan dalam memperagakan chest pass. Demikian hal ini dianggap penting untuk diperbaiki hasil belajarnya. Penelitian ini dilakukan atas dasar tingkat keberhasilan mahasiswa dalam perkuliahan bola basket masih rendah ketika tanpa variasi latihan drill. Dalam penelitian ini ada 1 teman sejawat sebagai pengamat yang bertugas memberikan penilaian dan semua temuan dari pengamat didiskusikan bersama untuk mengetahui bagaimana pemecahan masalah datam proses peningkatan hasil belajar chest pass bola basket. Hasil penelitian ini menunjukkan bahwa melalui penerapan variasi latihan drill terjadi peningkatan hasil chest pass bola basket mahasiswa PENJAS FKIP Universitas Bengkulu. Berdasarkan simpulan ini maka penerapan variasi latihan drill dapat dianjurkan sebagai konsep mengajar tambahan pada perkuliahan Bola Basket.
\end{abstract}

Kata Kunci: Latihan Drill, Bolabasket, Chest Pass

\begin{abstract}
This study aimed to improve the results of basketball chest pass learning which had a low success rate. Based on the above problems, it was necessary to make improvements in the lecture process, so that the learning outcomes target reached the KKM score. The success of lecturing was when the KKM value set by the study program achieved. The type of research was classroom action research with research subject students who took part in basketball lectures and lecturers who
\end{abstract}

PJKR

http://jurnal.unimed.ac.id/2012/index.php/jpehr 
taught basketball courses. The population in this study was the Physical Education Study Program at FKIP University of Dehasen Bengkulu, the sample was the Physical Education Study Program for Semester V Class A1. Chest pass was given at the beginning of the lecture, but students still had difficulties in demonstrating chest passes. Thus this matter was considered important to improve the learning outcomes. This research was conducted on the basis of the level of success of students in basketball lectures was still low when without variations in drill exercise. In this study there was 1 colleague as an observer who was in charge of providing assessment and all findings from observers were discussed together to find out how to solve problems in the process of improving the results of basketball chest pass learning. The results of this study indicated that through the application of variations in drill exercise there was an increase in the results of physical education students' FK basketball chest pass at the University of Bengkulu FKIP. Based on this conclusion, the application of variations in drill exercise was recommended as an additional teaching concept in Basketball lecture.

\section{Keywords: Drill Exercises, Basketball, Chest Pass}

\section{Introduction}

Basketball courses are compulsory courses in Physical Education courses. This subject is important for students of Physical Education courses because students after graduating from college then become physical education teachers must master various sports techniques, one of which is basketball. As a basic and compulsory subject in physical education study program, so students must graduate with a minimum grade of $\mathrm{C}$ or 2 with a scale of 1 to 4 . In the lecture process which has been conducted in the first week to the fourth, basketball material chest passes have been given. Chest pass is a Chest pass is a ball pass carried out by the thrower using two hands with the position of the hands at chest level and thrown to the recipient in the chest area. Chest pass techniques are relatively easy to practice, but after three weeks of teaching and learning there has not been any significant progress. Based on the tests that have been carried out it turns out there are $70 \%$ of students who still get grades $\mathrm{C}$ and $\mathrm{D}$, so on that basis there needs to be an improvement in the lecture process. Therefore it is necessary to apply a variety of drill exercises to improve the learning outcome of chest pass.

Sugihartono (2007) This drill training method is a method used by a person or group of people to guide students in accordance with their development towards the goals to be achieved through efforts to inculcate the habit of repeating certain exercises. It is expected that students can do it in a manner more optimal. Sugiyanto (1993) stated that the things to consider when using the drill method are: 1) The drill is used until the correct movement can be done automatically or become accustomed to, and stresses on certain circumstances the movement must be done. 2) Students are directed to concentrate on the correct implementation of the movement and the accuracy of its use. 3) During the drill it is necessary to

PJKR_

http://jurnal.unimed.ac.id/2012/index.php/jpehr 
always correct so that attention remains focused on the correctness of the motion. 4) The drill is adapted to the parts of the actual sports game situation. This can cause attraction in training. 5) It is necessary to do a transition exercise from the drill situation to the actual game situation. 6) Competitive atmosphere needs to be created in the drill, but there is still control over the correctness of its movements

This drill practice is the right method to help students improve their learning outcomes in basketball techniques. The basketball game itself was created by Dr. James A Naismith in 1891 in The United States of America, he was a physical education teacher. Imam Sodikun (1992) basketball is a sports game that uses large balls that are played by hand. Erla (2017) Basketball game is a game played by 5 players against 5 players who aim to get as many balls into the opponent's ring so as to achieve a victory. Feby E, Algifari S (2018) Basketball is a sport that is popular with students, including children.

In a basketball game, a ball can be passed (thrown at a friend), it can be reflected on the floor (on the spot or while walking) and the aim is to put the ball in the opponent's basket. One technique in the basketball game that is the basic technique of throwing and catching is often also referred to as operand or passing.

Nuril Ahmadi (2007), passing the ball with two hands from the front of the chest is a movement that is often done in a basketball game. Passing in this way will produce speed, accuracy, and precision. Throwing distance is 5 to 7 meters. Based on the description above that in learning basketball chest passes a beginner must be able to coordinate throwing and catching as explained above, in order to achieve mastery in learning the correct chest pass.

For this reason, educators must have this concept. Through this concept, it can improve student learning outcomes. The learning outcome referred to here is an evaluation result after carrying out the learning process. Winkel (1997) states that learning outcomes are evidence of success and effort made and are the abilities or skills obtained through learning activities in educational institutions expressed in numbers. Jihad (2009), according to him, learning outcomes are attainments of behavioral change that tend to settle from the cognitive, affective, and psychomotor domains of the learning process carried out within a certain time.

\section{Method}

This research method was a classroom action research method. There was an action / medicine conducted to correct weaknesses in learning the chest pass. Emzir (2012) action research was a process designed to empower all participants in the process (students, teachers, and other participants) with a view to improving practices held in the educational experience. Arikunto (2010) Action research was one of the problem solving strategies that utilized concrete actions in the form of innovative development processes that were "tried on the go" in detecting and solving problems.

The population in this study was the Physical Education Study Program at FKIP University of Dehasen Bengkulu, the sample was the Physical Education

PJKR

http://jurnal.unimed.ac.id/2012/index.php/jpehr 
students of Class A1 taken by purposive sampling because of the limitations of researchers. Sukardi (2003) technique for selecting samples which were nonprobability was to have a sample with an objective basis. This technique was also popularly referred to as purposive sampling. In the process, the parties involved in the activity could mutually support one another.

From some of the above theories it was clear that the research method to be carried out is classroom action research (Clasroom Action Research). In class action research which has four stages, namely: (1) Planning, (2) Implementation,

Observation,

Reflection.

Data analysis techniques, Sugiyono (2012) data analysis is an activity after the data from all respondents or other data sources are collected, data analysis activities are grouping data based on variables from all respondents, presenting data for each variable studied, doing calculations to answer the problem formulation, and perform calculations to test the hypothesis that has been proposed; Data reduction, data exposure.

\section{Discussion}

The results of the study were observations from peers and researchers, as well as feedback from students. Initial observations indicated that students still got below average. Seeing the conditions naturally made this observation finding to be immediately solved. From this observation it was seen that the KKM value had not been achieved in lecturing, the lecturer then discussed with colleagues to prepare a solution, which was in the form of an application of the drill exercise variations in lecturing activities.

Based on observations of the pre-cycle activities in this study, it was found that students were still lack mastering the chest pass technique with an average value of 50 (C) and only 4 students received a minimum grade of 75 (B). Furthermore, researchers provided drill exercises to see the ability of students in passing to the wall. At the end of the first cycle the researchers conducted a test. Chest pass test results in the first cycle obtained data as follows;

Table 1. Results of Chest Pass Cycle 1 Test

\begin{tabular}{lc}
\hline \multicolumn{1}{c}{ Completion } & Total of Students \\
\hline Completed & 14 \\
\hline Not Completed & 23 \\
\hline Total & 35 \\
\hline
\end{tabular}

From the table above, students who had not yet reached the minimum target of $75 \%$, namely only 14 people, the research continued to the second cycle.

Table 2. The Activeness of Students Results of Cycle I

\section{The Activeness of Students Results of Cycle I}

Active Medium Pasive




\begin{tabular}{|c|c|}
\hline $\begin{array}{l}\text { Students remain } \\
\text { enthusiastic even if called } \\
\text { or not called to do } \\
\text { instructions for learning } \\
\text { the Chest Pass }\end{array}$ & $\begin{array}{ll}\text { Students are enthusiastic } & \text { Students are not } \\
\text { about doing instructions } & \text { enthusiastic about doing } \\
\text { if called to do learning } & \text { instruction in Chest Pass } \\
\text { Chest Pass } & \end{array}$ \\
\hline Cycle I & \\
\hline : 10 Students & \\
\hline : 5 Students & \\
\hline : 20 Students & \\
\hline
\end{tabular}

Note: Enthusiastic $=$ Passionate, Enthusiastic $(\mathrm{KBBI})$

From table 2 above the lecture process was considered to be still not optimal because students who arrived late often interfere with other students already in the field, stretches become unfocused and so when apperception of students who arrived on time, fail to focus on students who arrived late. It was also seen that there were only 10 active students. Next follows, the results of the observation sheet of peers who observed the lecturer as a lecturer in the field in the first cycle;

Table 3. Observation Results of Peer Cycle 1

\begin{tabular}{llll}
\hline 1. & There is SAP and Syllabus & $\mathrm{V}$ \\
\hline 2. & Lecturer prepares lecturing equipment and facilities & $\mathrm{V}$ & \\
\hline 3. & The lecturer validates student & $\mathrm{V}$ & \\
\hline 4. & The lecturer opens the lecture by praying & $\mathrm{V}$ & \\
\hline 5. & $\begin{array}{l}\text { The lecturer gives apperception at the beginning of } \\
\text { each meeting }\end{array}$ & $\mathrm{V}$ & \\
\hline 6. & The lecturer gives a game activity before the core & $\mathrm{V}$ \\
\hline 7. & $\begin{array}{l}\text { Lecturer gives input and reinforcement during the } \\
\text { lecture process ysical Education, Health and Recreation }\end{array}$ & $\mathrm{V}$ \\
\hline 8. & $\begin{array}{l}\text { Lecturers are able to solve problems that arise during } \\
\text { lectures in progress }\end{array}$ & $\mathrm{V}$ & \\
\hline 9. & $\begin{array}{l}\text { Dos The lecturer closes the lecture with a lecture } \\
\text { evaluation and prayer }\end{array}$ & \multicolumn{1}{c}{ Total } & 7 \\
\hline
\end{tabular}

From the observations of the peers above, the game giving items were not implemented because of the presence of students when they were in college still $60 \%$. For the lecturer item, closing with the evaluation was carried out due to the dense lecture material, so that until the time was completed the material was not completed and the lecturer did not have the opportunity to give an evaluation. So from that the lecturers and peers agreed to continue the action to the second cycle then the lecture process in the second cycle was given a time limit of 10 minutes for students to enter after the lecture began, if more than 10 minutes then students were considered negligent. 
Following the observations of the chest pass test in the second cycle, the following data were obtained;

Table 4. Results of Chest Pass Cycle Test 2

\begin{tabular}{lc}
\hline \multicolumn{1}{c}{ Completion } & Total of Students \\
\hline Completed & 33 \\
\hline Not Completed & 2 \\
\hline Total & 35
\end{tabular}

From the results of the chest pass test in the second cycle, the lecturers and peers agreed to declare that the process of action stopped in the second cycle because the number of students who passed had exceeded the $75 \%$ target of $94 \%$.

Table 5. The Activeness of Students Results of Cycle II

The Activeness of Students Results of Cycle II

\section{Active}

\section{Active}

\section{Active}

Students are enthusiastic Students are enthusiastic Students are not even if called or not even if called or not enthusiastic to do called to do instructions called to do instructions instructions for learning for learning the Chest for learning the Chest the Chest Pass Pass Pass

Active : 33 Students

Medium : 1 Students

Pasive : 1 Students

Note: Enthusiastic $=$ Passionate, Enthusiastic $(\mathrm{KBBI})$

From the results of discussions with colleagues about the lecture process, the scores were maximal because students who arrived late were absent, stretching was the focus and so was the time of apperception before the material looked 'good'. This was illustrated from the results of student activity in the second cycle totaling 33 people. Following were the results of the observation sheet for the lecturer in the second cycle;

Table 6. Observation Results of Peer Cycle 2

\begin{tabular}{|c|l|c|c|}
\hline 1. & There is SAP and Syllabus & $\mathrm{V}$ & \\
\hline 2. & Lecturer prepares lecturing equipment and facilities & $\mathrm{V}$ & \\
\hline 3. & The lecturer validates student & $\mathrm{V}$ & \\
\hline 4. & The lecturer opens the lecture by praying & $\mathrm{V}$ & \\
\hline 5. & $\begin{array}{l}\text { The lecturer gives apperception at the beginning of each } \\
\text { meeting }\end{array}$ & $\mathrm{V}$ & \\
\hline 6. & The lecturer gives a game activity before the core & $\mathrm{V}$ & \\
\hline 7. & $\begin{array}{l}\text { Lecturer gives input and reinforcement during the lecture } \\
\text { process }\end{array}$ & $\mathrm{V}$ & \\
\hline 8. & $\begin{array}{l}\text { Lecturers are able to solve problems that arise during lectures } \\
\text { in progress }\end{array}$ & $\mathrm{V}$ & \\
\hline 9. & $\begin{array}{l}\text { The lecturer closes the lecture with a lecture evaluation and } \\
\text { prayer }\end{array}$ & $\mathrm{V}$ & \\
\hline & & 9 & \\
\hline
\end{tabular}

PJKR_

http://jurnal.unimed.ac.id/2012/index.php/jpehr 
From table 6 above, it is obtained that from 9 observation items, the lecturer has carried out all observation items well.

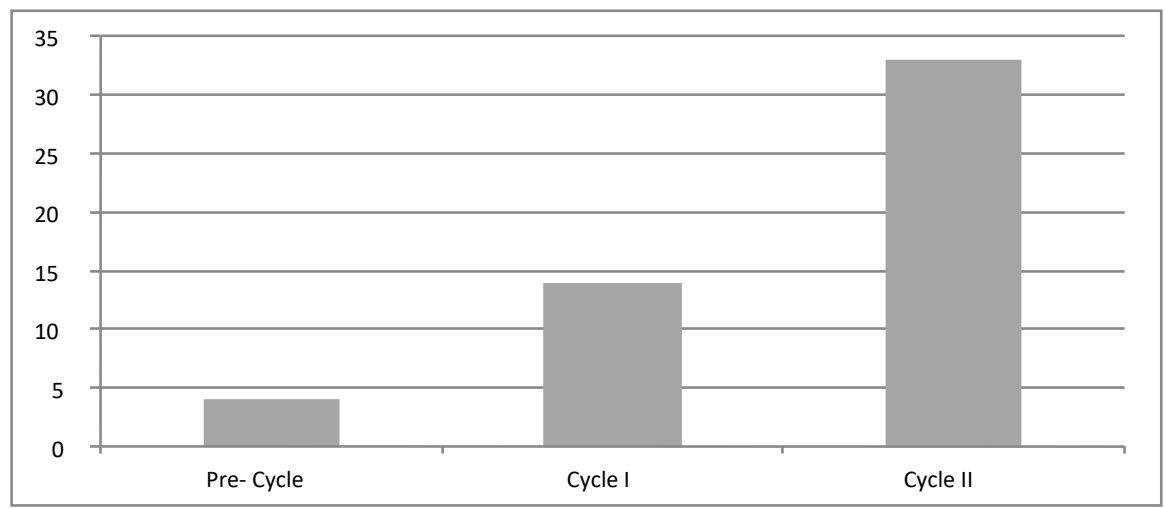

Based on, Figure 1 showed an increase in learning outcomes before the study, after cycle 1 , and after cycle 2 . At the time of pre-cycle students who got a value of $\mathrm{B}$ above $11 \%$. At the end of cycle 1 , those who received $\mathrm{B}$ grades and above experienced an increase of $40 \%$ students and in cycle 2 students who received B scores above $94 \%$ or had even exceeded the success indicators of this study.

The increase in learning outcomes was due to the more enthusiastic atmosphere of lectures which was observed through the activity sheet of lecture activity. Lectures before researching often occurr student delays then after giving rules lectures with a time allowed 10 minutes late then students had obeyed the rules. The application of an interesting variety of drill exercises made children motivated and active in the basketball lecture process. Basketball chest passes required strength and accuracy in passing the ball to someone's chest target. So through the application of variations of drill exercises students could be more enthusiastic and more leverage in moving the wrist when passing the ball.

Chest pass drill exercise was an operand ball exercise with the target of a person's chest done repeatedly using variations of movement. Good use of drills to the wall, a variety of triangular chest pass drills and paired drills. The application of drill exercises had provided increased student learning outcomes. Students were more likely to try, they were enthusiastic about practicing a variety of drill chest passes. Lectures became more lively and the results of chest pass learning become better than the previous lecture process.

\section{Conclusion}

The results showed that the application of drill practice was able to improve the learning outcomes of basketball chest passes for FKIP of Physical Education students at University of Dehasen Bengkulu. Based on this conclusion, the application of drill variations could be an additional teaching material in basketball lectures. 


\section{References}

Elra, Perdima, 2017. Bola Basket Dasar. Bengkulu: Universitas Dehasen Bengkulu Press.

Emzir, 2012. Metodologi Penelitian Kualitatif Analisis Data. Jakarta: PT. Raja Grafindo Persada.

Feby E, Algifari S, 2018. Kontruksi Battry Test Keterampilan Bola Basket Untuk Siswa Sekolah Dasar Kota Bengkulu. Journal Physical Education Health and Recreation. Volume: 3, Edisi: 1: 11-22.

Imam Sodikun, 1992. Olahraga Pilihan Bola Basket. Jakarta: Depdikbud.

Jihad, Asep, 2009. Evaluasi Pembelajaran. Yogyakarta: Multi Pressindo.

Nuril Ahmadi, 2007. Permainan Bolabasket. Solo: Era Intermedia.

Sugihartono, 2007. Metode latihan tingkat Keterampilan. Jakarta: PT Raja Grafindo Persada.

Sugiyono, 2012. Metode Penelitian Tindakan. Bandung: Alfabeta.

Sugiyanto, 1993. Belajar Gerak. Jakarta: KONI Pusat.

Suharsimi Arikunto, 2010. Prosedur Penelitian. Jakarta: Rineka Cipta.

Sukardi, 2003. Metodologi penelitian pendidikan kompetensi dan praktiknya. Jakarta: PT. Raja Grafindo Persada.

Winkel, WS, 1997. Psikologi Pendidikan dan Evaluasi Belajar Jakarta: Gramedia. 